\title{
Characterization of Tifton 85 bermudagrass haylage with different layers of polyethylene film and storage time
}

\author{
Caroline Daiane Nath', Marcela Abbado Neres ${ }^{1, *}$, Kácia Carine Scheidt ${ }^{2}$, Luciano dos Santos Bersot ${ }^{3}$, \\ Samantha Mariana Monteiro Sunahara ${ }^{1}$, Jaqueline Rocha Wobeto Sarto ${ }^{4}$, José Renato Stangarlin ${ }^{1}$, \\ Simone Damasceno Gomes ${ }^{5}$, Mallu Jagnow Sereno ${ }^{3}$, and Ana Paula Perin ${ }^{3}$
}

\footnotetext{
* Corresponding Author: Marcela Abbado Neres Tel: +55-45-3284-7912, Fax: +55-45-3284-7879,

E-mail: mabbadoneres@yahoo.com.br

${ }^{1}$ Department of Agricultural Science, State University of West Paraná, Marechal Cândido Rondon, PR 85960-000, Brazil

2 Department of Agricultural Science, State University of Maringá, Maringá, PR 87020-900, Brazil

${ }^{3}$ Department of Veterinary Science, Federal University of Palotina, Palotina, PR 85950-000, Brazil

${ }^{4}$ Department of Zootechny, São Paulo State University,

Botucatu, SP 18618-970, Brazil

${ }^{5}$ Department of Agricultural Engineering, State

University of West Paraná, Cascavel, PR 85819-110,

Brazil
}

\section{ORCID}

Caroline Daiane Nath

https://orcid.org/0000-0002-6996-5201

Marcela Abbado Neres

https://orcid.org/0000-0003-3221-4030

Kácia Carine Scheidt

https://orcid.org/0000-0001-8915-5305

Luciano dos Santos Bersot

https://orcid.org/0000-0001-7013-5574

Samantha Mariana Monteiro Sunahara

https://orcid.org/0000-0002-8777-6180

Jaqueline Rocha Wobeto Sarto

https://orcid.org/0000-0002-4944-7159

José Renato Stangarlin

https://orcid.org/0000-0001-8601-9439

Simone Damasceno Gomes

https://orcid.org/0000-0001-7639-8500

Mallu Jagnow Sereno

https://orcid.org/0000-0002-9665-2630

Ana Paula Perin

https://orcid.org/0000-0002-3711-5384

Submitted Aug 14, 2017; Revised Nov 30, 2017; Accepted Feb 8, 2018
Objective: The objective was to characterize the fermentative and microbiological profile of Tifton 85 bermudagrass haylage with different layers of polyethylene film and storage time. Methods: The experimental design consisted of a randomized block design with four and six wrapping layers (100 and 150 microns in total. respectively) allocated in the main plots, through repeated measures analysis (30,60, and 90 days of storage) with four replicates.

Results: The storage time and number of wrapping layers did not show changes in the population of Clostridium and lactic acid bacteria. A decrease was observed in the enterobacteria population with an increase in the storage period in the two wrapping layers studied. Upon opening of the haylage at 30 days, the population of Bacillus was lower in haylages made with six layers of wrapping (3.63 log colony forming units/g). No growth of Listeria sp. or Salmonella sp. was observed during the experimental period. The fungal genera with a greater occurrence were Penicillium sp. and Fusarium sp. The following mycotoxins were not detected: ochratoxin A, fumonisins, and zearalenone. Relative to the organic butyric, propionic, and acetic acids, the haylages presented a low concentration of lactic acid; this may have prevented a drop in the $\mathrm{pH}$, which was high when the silos were opened (5.4). The levels of ammoniacal nitrogen and soluble carbohydrates presented no variation among the number of wrapping layers, with an overall average of 35.55 and $38.04 \mathrm{~g} / \mathrm{kg}$.

Conclusion: Tifton 85 bermudagrass haylage wrapped with four and six layers presented adequate fermentation and microbiological characteristics in the evaluated periods.

Keywords: Cynodon; Dehydration; Fermentation; Forage; Microorganisms

\section{INTRODUCTION}

The principle of forage conservation through haylage is based on anaerobic fermentation, aiming to provide sufficient amounts of lactic acid to promote a drop in $\mathrm{pH}$ and inhibit undesirable microorganisms, while also aiming to conserve the nutritional value and characteristics of the food as close as possible to the original forage. However, for these conditions to be achieved, the forage must have adequate amounts of fermentable substrate, relatively low buffer capacity (BC), and dry matter (DM) content above $300 \mathrm{~g} / \mathrm{kg}[1]$.

However, tropical forages present unfavorable intrinsic characteristics in the stages of growth in which they present good nutritional value [2], putting the conservation process at risk due to the occurrence of undesirable secondary fermentations. Optionally, to circumvent low DM content, pre-drying or wilting of the material to be ensiled provides an excellent technological alternative for improving the fermentation pattern of the tropical forage haylages.

Haylage formed into polyethylene film-coated cylindrical bales is packed with a higher 
concentration of DM [3], stored with a lower bulk density [4], and has a larger surface area in contact with the plastic film compared to conventional silage [5]. Therefore, this haylage is more susceptible to air penetration because the physical properties of the polyethylene films can be altered during the storage period, affecting the permeability of gases due to excessive exposure to high ambient temperature and solar radiation [6]. Thus, the number of layers of the plastic film used in the silo sealing is critical to prevent oxygen penetration into the ensiled material and thus control the growth of microorganisms that cause deterioration of the haylages.

In the silage process, the prolongation of storage time can influence the nutritive value and the fermentation profile of the silages. In tropical conditions, the conservation time of forages in the form of haylage is shorter and the preserved roughage source loses stability at approximately 60 days of storage. With this purpose, the study meets one of the producers' demands: to understand the mechanisms that cause this roughage source in the form of haylage to have poorer stability when conserved.

The objective of this study was to characterize the fermentative and microbiological profile of Tifton 85 bermudagrass haylage with different layers of polyethylene film and storage time.

\section{MATERIALS AND METHODS}

\section{Location}

The experiment was conducted at a Cynodon sp. cv. Tifton 85 pre-drying production site, located in the municipality of Marechal Cândido Rondon, PR, Brazil, at the following geographical coordinates: latitude $24^{\circ} 33^{\prime} 40^{\prime \prime} \mathrm{S}$, longitude $54^{\circ}$ $04^{\prime} 12^{\prime \prime} \mathrm{W}$, and altitude $420 \mathrm{~m}$. The local climate, classified according to Köppen, is of type Cfa, subtropical, with rains well distributed throughout the year and hot summers. During the experimental period, the accumulated rainfall was 202.2 $\mathrm{mm}$, and the mean temperatures were a minimum of $21.3^{\circ} \mathrm{C}$, maximum of $28.4^{\circ} \mathrm{C}$, and mean of $25.2^{\circ} \mathrm{C}$.

\section{Experimental area}

The soil is classified as Oxisol Ustox Eutrustox [7] of clayey texture $(554.80 \mathrm{~g} / \mathrm{kg}$ clay, $359.08 \mathrm{~g} / \mathrm{kg}$ silt and $58.82 \mathrm{~g} / \mathrm{kg}$ sand) and presented the following chemical characteristics: $\mathrm{pH}$ $\left(\mathrm{CaCl}_{2}\right)$ 5.24, P (Mehlich) $33.72 \mathrm{mg} / \mathrm{dm}^{3}, \mathrm{~K}$ (Mehlich) 0.11 $\mathrm{cmol}_{c} / \mathrm{dm}^{3}, \mathrm{Ca}^{2+}(\mathrm{KCl} 1 \mathrm{~mol} / \mathrm{L}) 5.88 \mathrm{cmol}_{\mathrm{c}} / \mathrm{dm}^{3}, \mathrm{Mg}^{2+}(\mathrm{KCl} 1$ $\mathrm{mol} / \mathrm{L}) 1.91 \mathrm{cmol}_{\mathrm{c}} / \mathrm{dm}^{3}, \mathrm{Al}^{3+}(\mathrm{KCl} 1 \mathrm{~mol} / \mathrm{L}) 0.60 \mathrm{cmol}_{\mathrm{c}} / \mathrm{dm}^{3}, \mathrm{H}+$ $\mathrm{Al}$ (Ca acetate $0.5 \mathrm{~mol} / \mathrm{L}) 4.65 \mathrm{cmol}_{\mathrm{c}} / \mathrm{dm}^{3}, \mathrm{SB} 7.89 \mathrm{cmol}_{\mathrm{c}} / \mathrm{dm}^{3}$, CEC $12.54 \mathrm{cmol}_{\mathrm{c}} / \mathrm{dm}^{3}, \mathrm{~V} 63 \%$, organic matter $23.10 \mathrm{~g} / \mathrm{dm}^{3}$, $\mathrm{Cu} 26.87 \mathrm{mg} / \mathrm{dm}^{3}, \mathrm{Zn} 30.06 \mathrm{mg} / \mathrm{dm}^{3}, \mathrm{Mn} 87.77 \mathrm{mg} / \mathrm{dm}^{3}$, and $\mathrm{Fe} 21.60 \mathrm{mg} / \mathrm{dm}^{3}$.

The area used for forage harvesting and haylage preparation was established in 2006 with Tifton 85 bermudagrass and periodically receives pig biofertilizer as the sole source of fertilizer from a Canadian model biodigester; according to Normative Instruction No. 17 of June 18, 2014, the use of biostabilized manure, that is, manure that has undergone anaerobic fermentation in biodigesters, is allowed.

The biofertilizer is applied to the surface of the forage area by spraying, with equipment coupled to the tractor, on the 7th and 14th days of regrowth of the forage, with an average of 60 $\mathrm{m}^{3} /$ ha biofertilizer/application. The biofertilizer presented the following composition: $1.17 \mathrm{~g} / \mathrm{kg} \mathrm{N}, 0.27 \mathrm{mg} / \mathrm{kg} \mathrm{K}, 0.40 \mathrm{mg} / \mathrm{kg}$ Ca, $0.06 \mathrm{mg} / \mathrm{kg} \mathrm{Mg}, 1.68 \mathrm{mg} / \mathrm{kg} \mathrm{Cu}, 0.65 \mathrm{mg} / \mathrm{kg} \mathrm{Zn,} 0.24 \mathrm{mg} / \mathrm{kg}$ $\mathrm{Mn}, 1.50 \mathrm{mg} / \mathrm{kg} \mathrm{Fe}$, and $0.02 \mathrm{mg} / \mathrm{kg}$ P.

\section{Silage and storage}

The Tifton 85 bermudagrass was cut on 17 Nov. 2014, at 03:30 $\mathrm{pm}$, when the forage was physiologically equivalent to 35 days of growth and had a DM content of $296.00 \mathrm{~g} / \mathrm{kg}$. The bermudagrass was harvested with a finger-type mower conditioner, adjusted to a cutting height $5 \mathrm{~cm}$ from the ground.

The material was submitted to wilting to obtain increased DM contents in silage. After 17 hours and 30 minutes of weather exposure, when the forages reached $540.15 \mathrm{~g} / \mathrm{kg} \mathrm{DM}$ ( 18 Nov 2014, at 11:00 am), the forage was wrapped in the form of rolls (400 kg each) approximately $100 \mathrm{~cm}$ in height and 150 $\mathrm{cm}$ in diameter using a baler. Soon after, the rolls were automatically wrapped with four and six overlapping layers of milky-white stretch polyethylene film, $25 \mu \mathrm{m}$ thick and totaling $100 \mu \mathrm{m}$ and $150 \mu \mathrm{m}$ for four and six layers, respectively.

Commercial inoculant (BactoSilo AMS, Cambé, PR, Brazil), comprising Lactobacillus buchneri and Propionibacterium acidipropionici at concentrations of approximately $20 \times 10^{9}$ and $30 \times 10^{9}$ colony forming units (CFU)/g, respectively, was added to the forage at baling through a container coupled to the baler. The application of the inoculant was performed according to the manufacturer's recommendations. The haylage rolls were stored under field conditions exposed to the weather. After each storage period, the silos were opened, and samples were aseptically collected for the microbiological and fermentative analyses.

\section{Parameters analyzed}

The populations of microorganisms were determined in duplicate by means of crop techniques according to Silva et al [8], using the following media: Lactobacillus MRS Broth for counting lactic acid bacteria (LAB), with the plates incubated at $30^{\circ} \mathrm{C}$ for 48 hours; Violet Red Bile Agar for counting enterobacteria, with the plates maintained and incubated at $36^{\circ} \mathrm{C}$ for 24 hours; and Reinforced Clostridial Agar for Clostridium counting, with the plates incubated for 24 hours in a greenhouse with carbon dioxide system at $36^{\circ} \mathrm{C}$. The isolation of Bacillus was performed according to Speck [9], using nutrient agar medium and incubation of the plates for 72 hours in an 
oven at $30^{\circ} \mathrm{C}$. Microbiological analyses of Listeria sp. and Salmonella sp. were based on Normative Instruction No. 62, of August 26, 2003, of the Ministry of Agriculture, Livestock and Supply - MAPA.

For an evaluation of fungi and yeast, the diluted extracts were seeded on plates containing Potato Dextrose Agar medium and incubated at room temperature for seven days. From observation made with a stereoscopic microscope (magnifying glass), slides of the fungal structures were prepared. These structures were transferred using a needle to a microscope slide with lactophenol cotton blue dye, covered with cover slip, enamel-sealed, and observed under an optical microscope to identify the genus of the fungi from the morphological characteristics observed [10].

After the incubation of the bacteria and fungi, the colonies were counted using a Quebec colony counter, and the plaques that presented among 30 and $300 \mathrm{CFU}$ per Petri dish were counted, with the results expressed in log of CFU/g.

The mycotoxicological analyses were performed at the Laboratory of Mycotoxicological Analyses (LAMIC), of the Federal University of Santa Maria (UFSM), Santa Maria/RS, Brazil. The concentrations of zearalenone (ZEA), ochratoxin A (OTA), and fumonisins (FB1 and FB2) were determined. The analyses were performed by high-performance liquid chromatography (HPLC) methods using an Agilent 1200 series HPLC system and liquid chromatography-mass spectrometry (LC-MS/MS) using an API 5000 LC/MS/MS system.

For the evaluation of the fermentative process, the following was determined: the soluble carbohydrate contents, according to Johnson et al [11] the BC and ammoniacal nitrogen, according to Bolsen et al [12]; and the $\mathrm{pH}$, according to Cherney and Cherney [13]. The fermentation capacity (FC) of the ensiled material was calculated according to the equation proposed by Weissbach and Honing [14]: $\mathrm{FC}=\mathrm{DM}+8$ (SC/BC), where $\mathrm{DM}$ is expressed as \%, soluble carbohydrates (SCs) are expressed as \% of $\mathrm{DM}$, and $\mathrm{BC}$ is expressed in e.mg $\mathrm{HCl} / 100 \mathrm{~g}$ of DM.

For the determination of the organic acids (lactic, acetic, propionic, and butyric) in the haylage, $1.5 \mathrm{~g}$ of the sample was macerated in a porcelain mortar with pestle and liquid nitrogen. The resulting macerate was diluted with $13.5 \mathrm{~mL}$ of deionized water purified in a Milli-Q system and then centrifuged at $12,000 \mathrm{rpm}$ for 10 minutes at $15^{\circ} \mathrm{C}$. The supernatant was removed, filtered on a membrane of nitrate-cellulose ( 0.45 $\mu \mathrm{m}$ and $0.20 \mu \mathrm{m}$ pore) and subjected to chromatographic analysis by HPLC. The equipment consisted of an autosampler (LKB model 2157, Uppsala, Sweden), HPLC-pump (LKB model 2150, Sweden), and a cation exchange resin column (Aminex HPX-87H, 300×7.8 mm, Bio-Rad, Hercules, CA, USA). The mobile phase consisted of $\mathrm{H} 2 \mathrm{SO} 4$ and was eluted at a flow rate of $0.6 \mathrm{~mL} / \mathrm{min}$ at $40^{\circ} \mathrm{C}$.

\section{Statistical analysis}

The data were analyzed in a randomized block design, with repeated measures. A mixed model with the fixed effect of the wrapping layers (1DF), silo-opening days (2DF), and their interactions (2DF), and the random effect of the bags inside the wrapping (12DF) with the MIXED procedure of SAS University Edition were used. Among all the error structures investigated, the first-order autoregressive structure AR (1) was the best according to the Bayesian information criterion. In all analyses, significance was defined as $\mathrm{p} \leq 0.05$. In the counting and identification of the yeast and fungi genera, the means were calculated, and these were submitted to the descriptive analysis of the data by means of graphs.

\section{RESULTS AND DISCUSSION}

The microbiological population and fermentation profile of Tifton 85 bermudagrass before ensiling are shown in Table 1 .

The levels of ammoniacal nitrogen (total $\mathrm{NH}_{3} / \mathrm{N}$ ) were not affected ( $p>0.05$ ) by the number of wrapping layers (Table 2 ). In haylages made with four and six wrapping layers, a difference $(\mathrm{p}<0.05)$ was observed in the total $\mathrm{NH}_{3} / \mathrm{N}$ content among the storage times, but all values were within an adequate range to allow satisfactory fermentation and to prevent undesirable fermentation, which occurs in ensiled forages with total $\mathrm{NH}_{3} / \mathrm{N}$ contents above $150.0 \mathrm{~g} / \mathrm{kg}$ [1]. Lower levels of ammoniacal nitrogen indicate a lower proteolysis intensity during the fermentation process of the silages due to the lower performance of clostridial bacteria and, consequently, the lower production of butyric acid [1].

In the present study, the inclusion of the commercial inoculant in the Tifton 85 bermudagrass haylage was aimed at increasing the population of lactic acid bacteria to improve the fermentation pattern and the aerobic stability of silage in all treatments, because according to McDonald et al [1], the original count of epiphytic lactic bacteria in forage is a factor to be considered for addition of inoculant in the silage, because

Table 1. Microbiological population and fermentation profile of Tifton 85 bermudagrass before ensiling

\begin{tabular}{ll}
\hline Variable & \\
\hline Bacillus (log CFU/g) & 3.63 \\
Clostridium (log CFU/g) & 4.40 \\
Enterobacteria (log CFU/g) & 4.05 \\
Lactic acid bacteria (log CFU/g) & 3.97 \\
Total fungi (log CFU/g) & 0.83 \\
Fermentation capacity (g/kg) & 37.03 \\
Buffer capacity (meq NaOH/100 g of DM) & 16.22 \\
Soluble carbohydrates (g/kg) & 43.78 \\
Ammoniacal nitrogen (g/kg) & 3.44 \\
pH & 5.14
\end{tabular}

CFU, colony forming units; DM, dry matter. 
Table 2. Ammonia nitrogen, soluble carbohydrates, and pH in Tifton 85 bermudagrass haylage wrapped with different layers of polyethylene film at 30 , 60 , and 90 days of storage

\begin{tabular}{|c|c|c|c|}
\hline Items & 30 days & 60 days & 90 days \\
\hline \multicolumn{4}{|l|}{ Ammonia nitrogen (g/kg) } \\
\hline 4 layers & $30.75^{\mathrm{aB}}$ & $43.17^{\mathrm{aA}}$ & $39.25^{\mathrm{aAB}}$ \\
\hline 6 layers & $27.99^{\mathrm{aB}}$ & $38.13^{\mathrm{aA}}$ & $34.05^{\mathrm{aAB}}$ \\
\hline \multicolumn{4}{|l|}{ SEM } \\
\hline Wrapped & & 2.2773 & \\
\hline Storage period & & 2.5394 & \\
\hline Wrapped $\times$ storage period & & 3.5913 & \\
\hline \multicolumn{4}{|l|}{ Soluble carbohydrates (g/kg) } \\
\hline 4 layers & $42.83^{\mathrm{aA}}$ & $39.09^{\mathrm{aAB}}$ & $32.29^{\mathrm{aB}}$ \\
\hline 6 layers & $43.81^{\mathrm{aA}}$ & $36.72^{\mathrm{aAB}}$ & $33.57^{\mathrm{aB}}$ \\
\hline \multicolumn{4}{|l|}{ SEM } \\
\hline Wrapped & & 1.5080 & \\
\hline Storage period & & 2.0697 & \\
\hline Wrapped $\times$ storage period & & 2.9269 & \\
\hline \multicolumn{4}{|l|}{ re } \\
\hline 4 layers & $5.76^{\mathrm{aA}}$ & $6.03^{\mathrm{aA}}$ & $4.88^{\mathrm{aB}}$ \\
\hline 6 layers & $5.69^{\mathrm{aA}}$ & $5.58^{\mathrm{bA}}$ & $5.04^{\mathrm{aB}}$ \\
\hline \multicolumn{4}{|l|}{ SEM } \\
\hline Wrapped & & 0.0521 & \\
\hline Storage period & & 0.0658 & \\
\hline Wrapped $\times$ storage period & & 0.0931 & \\
\hline
\end{tabular}

SEM, standard error of the mean.

${ }_{a, b}$ Mean with different superscript within a column differ at $p<0.05$.

${ }^{A B}$ Mean with different superscript within a row differ at $p<0.05$.

in tropical forages, these microorganisms are about 1,000 times less abundant than fungi and enterobacteria. However, the low levels of soluble carbohydrates present in the plant may have compromised the effective action of the inoculant, reducing the production and multiplication of lactic acid bacteria, responsible for stabilizing the $\mathrm{pH}$ of the silo and inhibiting undesirable microorganisms. In a future study, a source of soluble carbohydrates should be added to the fodder along with the inoculant, for a more effective action.

The levels of SCs (CHOs) differed $(\mathrm{p}<0.05)$ among the storage times in the haylages made with four and six layers of wrapping and were below the appropriate levels (80 to 100 $\mathrm{g} / \mathrm{kg}$ ) recommended by McDonald et al [1] for good fermentation. Adequate levels of SCs in haylages favor the establishment and growth of lactic-acid-producing bacteria, which promote the reduction of $\mathrm{pH}$ and the conservation of the ensiled material. According to Neres et al [15], tropical bermudagrass silages present low soluble carbohydrate concentrations among 20 and $50 \mathrm{~g} / \mathrm{kg}$, corroborating the results of the present study.

The FC of Tifton 85 bermudagrass one day before ensilage $(37.03 \mathrm{~g} / \mathrm{kg})$ shows a high potential for forage ensilability, because according to Coan et al [16] FC values greater than 35 $\mathrm{g} / \mathrm{kg}$ guarantee that fermentation is adequate to obtain lactic silage. Relative to the $\mathrm{BC}$ of the forage one day before ensilage, the mean values obtained (16.22 meq NaOH/100 g of DM) were low, contradicting the assertion that perennial bermudagrasses have a high buffering capacity [17], which allows the bermudagrasses to resist a change in $\mathrm{pH}$.

At the opening of the silos, the $\mathrm{pH}$ values differed $(\mathrm{p}<0.05)$ among the storage periods and wrapping layers at 60 days of ensilage. The values obtained exceeded the upper limit (4.2) suggested by McDonald et al [1] as favorable for the adequate conservation of food in the form of silages. High forage moisture at ensilage ( $540.15 \mathrm{~g} / \mathrm{kg} \mathrm{DM})$ and low levels of fermentable carbohydrates may have contributed to high $\mathrm{pH}$ values. The data obtained corroborate those of Coblentz et al [3] who evaluated the involvement of haylage alfalfa bales with stretch film with and without an oxygen barrier and obtained $\mathrm{pH}$ mean values (5.76) unfavorable for forage conservation.

A significant decrease was observed in the enterobacteria population $(\mathrm{p}<0.05)$ with an increase in the storage period in both treatments (Table 3), due to the reduction of $\mathrm{pH}$ during the storage period because the development of these microorganisms is inhibited at a pH below 4.5 [18]. Similar behavior was observed by Li and Nishino [19], who quantified a population of enterobacteria of $10^{5}$ and $10^{7} \log \mathrm{CFU} / \mathrm{g}$ in ryegrass and Panicum maximum haylage, respectively, up to the 28th day of storage, whereas the population at 56 and 120 days of storage was below the detectable level $\left(10^{2} \log \mathrm{CFU} / \mathrm{g}\right)$ due to the reduction in the $\mathrm{pH}$ in the preserved roughages. The development of enterobacteria is undesirable in silages due to the degradation of the proteins by these microorganisms; this degradation causes a reduction in the nutritive value in the roughage and in the production of amines and branched fatty acids, which negatively affect the palatability of the silage [20].

The Bacillus population showed an interaction among the number of wrapping layers and storage time, with a lower $(\mathrm{p}<$ 0.05 ) Bacillus count in haylage with six layers of wrapping at 30 days of storage. The occurrence of Bacillus spores in silages due to land contamination and/or the use of manure as fertilizer in the crop [21] is a concern to milk producers, because these spores can survive pasteurization, and some strains are capable of germination and growth under refrigerated conditions in pasteurized milk [22].

The development of Clostridium and LAB did not show variations among treatments $(p>0.05)$, with an overall mean of 5.93 and $6.01 \log \mathrm{CFU} / \mathrm{g}$, respectively. According to $\mathrm{Ni}$ et al [23], lactic acid bacteria are responsible for acidification of silage to the extent that undesirable microorganisms are not able to survive, resulting in stable roughages with low $\mathrm{pH}$. However, in the present study, the LAB population was lower than the minimum limit $\left(10^{8} \mathrm{CFU} / \mathrm{g}\right)$ desirable for an appropriate fermentation of the silages [24] consequently influencing the high values of $\mathrm{pH}$ during the storage of the roughages.

Neres et al [25], did not observe the development of enterobacteria in Tifton 85 bermudagrass silage that were ensiled in poly (vinyl chloride) experimental silos after 30 days of stor- 
Table 3. Population of bacteria (log CFU/g) in Tifton 85 bermudagrass haylage wrapped with different layers of polyethylene film at 30,60, and 90 days of storage

\begin{tabular}{|c|c|c|c|c|c|c|}
\hline Items & 30 days & 60 days & 90 days & 30 days & 60 days & 90 days \\
\hline & \multicolumn{3}{|c|}{ Enterobacteria } & \multicolumn{3}{|c|}{ Bacillus } \\
\hline 4 layers & $3.92^{2 \mathrm{~A}}$ & $3.30^{\mathrm{aB}}$ & $2.01^{a c}$ & $5.08^{2 \mathrm{~A}}$ & $4.27^{2 \mathrm{~A}}$ & $4.61^{\mathrm{AA}}$ \\
\hline 6 layers & $3.70^{\mathrm{aA}}$ & $3.44^{2 \mathrm{~A}}$ & $2.01^{\mathrm{aB}}$ & $3.63^{\mathrm{bB}}$ & $5.03^{\mathrm{aA}}$ & $4.90^{\mathrm{AA}}$ \\
\hline \multicolumn{7}{|l|}{ SEM } \\
\hline Wrapped & \multicolumn{3}{|c|}{0.0701} & \multicolumn{3}{|c|}{0.1910} \\
\hline Storage period & \multicolumn{3}{|c|}{0.0902} & \multicolumn{3}{|c|}{0.2322} \\
\hline \multirow[t]{2}{*}{ Wrapped $\times$ storage period } & \multicolumn{3}{|c|}{0.1276} & \multicolumn{3}{|c|}{0.3284} \\
\hline & \multicolumn{3}{|c|}{ Clostridium } & \multicolumn{3}{|c|}{ Lactic acid bacteria } \\
\hline 4 layers & $6.21^{\mathrm{aA}}$ & $5.82^{\mathrm{aA}}$ & $5.95^{\mathrm{aA}}$ & $6.43^{\mathrm{aA}}$ & $5.67^{\mathrm{aA}}$ & $6.08^{\mathrm{aA}}$ \\
\hline 6 layers & $5.75^{2 \mathrm{~A}}$ & $5.88^{8 \mathrm{~A}}$ & $5.99^{\mathrm{aA}}$ & $5.98^{2 \mathrm{~A}}$ & $6.10^{\mathrm{aA}}$ & $5.83^{\mathrm{aA}}$ \\
\hline \multicolumn{7}{|l|}{ SEM } \\
\hline Wrapped & & 0.1603 & & & 0.1664 & \\
\hline Storage period & & 0.1599 & & & 0.1719 & \\
\hline Wrapped $\times$ storage period & & 0.2261 & & & 0.2431 & \\
\hline
\end{tabular}

CFU, colony forming units; SEM, standard error of the mean.

a,b Mean with different superscript within a column differ at $p<0.05$.

${ }^{A-C}$ Mean with different superscript within a row differ at $p<0.05$.

age, whereas the Clostridium and LAB count was 7.00 and $4.39 \log \mathrm{CFU} / \mathrm{g}$, respectively.

When the silos were opened, an absence of Salmonella sp. and Listeria sp. was noted for the analyzed samples. These results differed from those obtained by Schocken-Iturrino et al [26], who observed the presence of Listeria sp. in $65.6 \%$ of the samples of Tifton 85 bermudagrass silage at the opening of the silos. The development of Salmonella sp. and Listeria $\mathrm{sp}$. is directly linked to the $\mathrm{pH}$ of the haylage, inhibiting the growth of Listeria sp. at a pH close to 5.2 [26] and growth of Salmonella sp. at a $\mathrm{pH}$ close to 7.0 [27]. The development of these deteriorating and pathogenic microorganisms in haylages adversely affects the physico-chemical quality of the roughage in addition to having a detrimental effect on animal health and well-being, while also interfering with the quality of milk produced by the animals fed with these contaminated haylages.

The genera of the fungi found in the haylages were Penicillium, Fusarium, Aspergillus, Rhizophus, and Bipolaris, and the first two showed a higher occurrence in most haylages at different storage times (Figures 1,2). Similar results were obtained by [26], who quantified the fungal population in silages of Tifton 85 bermudagrass at the opening of the silos after 80 days of ensilage and found a predominance of the genera Penicillium and Fusarium.

By evaluating the presence of fungi in the haylages with four layers of wrapping, a higher occurrence of fungi and yeasts in the haylages was observed after 60 days of storage, which may be associated with the high $\mathrm{pH}$ recorded in this period (Figure 1). At the silo openings at 30 days, a larger population

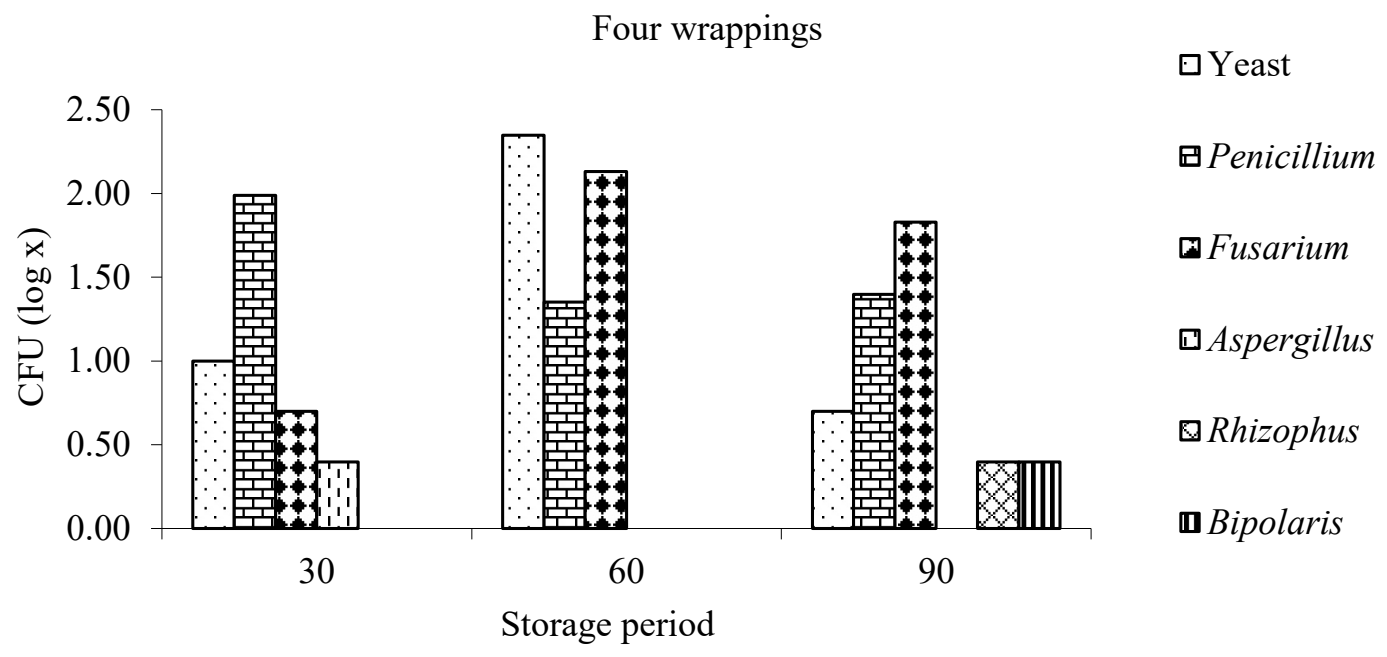

Figure 1. Yeast and fungal genera after opening at 30,60, and 90 days of anaerobic fermentation of Tifton 85 bermudagrass haylage wrapped with four layers of polyethylene film. 


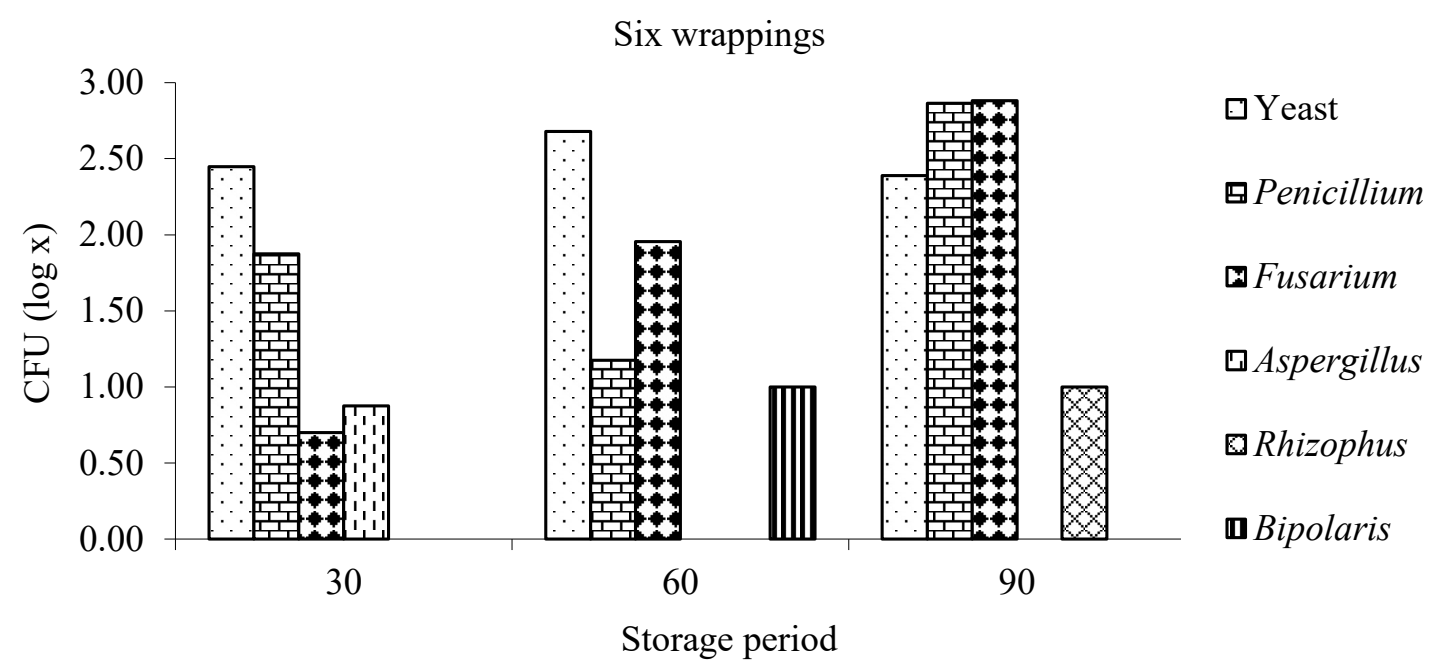

Figure 2. Yeast and fungus genera after opening at 30,60, and 90 days of anaerobic fermentation of Tifton 85 bermudagrass haylage wrapped with six layers of polyethylene film.

of Penicillium fungi was observed, and at 60 and 90 days, the Fusarium genus was more frequently observed.

In the haylages with six layers of wrapping, a higher yeast population was observed at 30 and 60 days of storage, and a higher fungi population was observed at 90 days of storage. The largest population of Penicillium fungi occurred at 30 days, and the largest population of Fusarium occurred at 60 and 90 days of ensilage (Figure 2).

Pathogenic genera such as Aspergillus, Fusarium, and Penicillium are the most commonly found in silages [28] and are dominant in their capacity to produce toxins, which can lead to damage to the health of animals when ingested and to the health of people when handling roughage food, in addition to causing changes in the chemical composition of the silages
[29].

Although of Tifton 85 bermudagrass showed fungal development, mycotoxin levels in bermudagrass and haylage at 30,60 , and 90 days of storage are below the quantification limit of the methods used to analyze fumonisins $(125 \mu \mathrm{g} / \mathrm{kg})$, OTA $(2.5 \mu \mathrm{g} / \mathrm{kg})$, and ZEA $(20 \mu \mathrm{g} / \mathrm{kg})$.

Acetic acid levels differed $(\mathrm{p}<0.05)$ among the storage periods and wrapping layers (Table 4 ), and the acid values in the haylages with four layers of wrapping at 60 days of storage exceeded the limit of $8.00 \mathrm{~g} / \mathrm{kg} \mathrm{DM}$ which, according to McDonald et al [1], is the reference for classification of silages as "good quality". High levels of acetic acid occur due to the presence of heterolactic bacteria and indicate undesirable changes during fermentation, causing a reduction in silage consump-

Table 4. Concentration of organic acids (g/kg MS) in Tifton 85 bermudagrass haylage wrapped with different layers of polyethylene film, at 30,60, and 90 days of storage

\begin{tabular}{|c|c|c|c|c|c|c|}
\hline Items & 30 days & 60 days & 90 days & 30 days & 60 days & 90 days \\
\hline & \multicolumn{3}{|c|}{ Acetic } & \multicolumn{3}{|c|}{ Propionic } \\
\hline 4 layers & $4.85^{\mathrm{aB}}$ & $9.80^{\mathrm{aA}}$ & $6.12^{\mathrm{aB}}$ & $0.72^{\mathrm{aA}}$ & $0.48^{\mathrm{aB}}$ & $0.70^{\mathrm{aA}}$ \\
\hline 6 layers & $5.23^{\mathrm{aA}}$ & $5.49^{\mathrm{bA}}$ & $4.36^{\mathrm{aA}}$ & $0.39^{\mathrm{bA}}$ & $0.55^{\mathrm{aA}}$ & $0.48^{\mathrm{bA}}$ \\
\hline \multicolumn{7}{|l|}{ SEM } \\
\hline Wrapped & & 0.5995 & & & 0.0335 & \\
\hline Storage period & & 0.6929 & & & 0.0408 & \\
\hline \multirow[t]{2}{*}{ Wrapped $\times$ storage period } & \multicolumn{3}{|c|}{0.9800} & \multicolumn{3}{|c|}{0.0577} \\
\hline & & Butyric & & & Lactic & \\
\hline 4 layers & $0.66^{\mathrm{aB}}$ & $0.71^{\mathrm{aAB}}$ & $0.85^{\mathrm{aA}}$ & $17.37^{\mathrm{AA}}$ & $17.26^{\mathrm{aA}}$ & $12.86^{\mathrm{aA}}$ \\
\hline 6 layers & $0.61^{\mathrm{aA}}$ & $0.73^{\mathrm{aA}}$ & $0.67^{\mathrm{bA}}$ & $19.85^{\mathrm{aA}}$ & $15.03^{\mathrm{aB}}$ & $9.33^{\mathrm{ac}}$ \\
\hline \multicolumn{7}{|l|}{ SEM } \\
\hline Wrapped & & 0.0398 & & & 1.1219 & \\
\hline Storage period & & 0.0414 & & & 1.1802 & \\
\hline Wrapped $\times$ storage period & & 0.0585 & & & 1.6690 & \\
\hline
\end{tabular}

SEM, standard error of the mean.

${ }^{a, b}$ Mean with different superscript within a column differ at $p<0.05$.

A-c Mean with different superscript within a row differ at $p<0.05$. 
tion by the animals. Results superior to those observed in this experiment were previously reported by Neres et al [15], who obtained mean acetic acid values of $42.38 \mathrm{~g} / \mathrm{kg}$ DM in Tifton 85 bermudagrass haylage at 30 days of storage.

For the concentrations of propionic acid, interactions among the storage periods and the wrapping layers $(\mathrm{p}<0.05)$ were observed, with content variation from 0.39 to $0.72 \mathrm{~g} / \mathrm{kg} \mathrm{DM}$. Coblentz et al [3], observed propionic acid values of 1.1 and $1.4 \mathrm{~g} / \mathrm{kg} \mathrm{DM}$, in haylage alfalfa silages wrapped with stretch film with and without oxygen barrier, respectively. According to Roth et al [30], the presence of propionic acid above the established limit (5.00 $\mathrm{g} / \mathrm{kg} \mathrm{DM})$ represents the degradation of lactic acid by butyric bacteria, a situation totally discounted in the present work.

The levels of butyric acid were higher $(\mathrm{p}>0.05)$ in haylage with four layers of wrapping at 90 days of storage, but all values were lower than $1.0 \mathrm{~g} / \mathrm{kg} \mathrm{DM}$, which characterizes silages with desirable fermentation [1]. The large Clostridium population observed during the fermentation process resulted in low butyric acid production, most likely because the bacteria growth were probably found in the stationary state, when the acid production reactions are still low. It is possible that the evaluation at 120 days of storage would present a greater production of butyric acid.

In roughages with six layers of wrapping, the lactic acid content decreased with an increase in the storage period $(\mathrm{p}>$ 0.05 ). The levels of lactic acid observed in the haylages were below the level considered satisfactory (above $50 \mathrm{~g} / \mathrm{kg} \mathrm{DM}$ ) according to McDonald et al [1], which may mean that prolonging the storage period hampered the development of homofermentative lactic acid bacteria and that high $\mathrm{pH}$ values can be attributed to such low lactic acid production. The values of lactic acid were not affected $(p>0.05)$ by the number of wrapping layers.

Tifton 85 bermudagrass haylage wrapped with four and six layers presented adequate fermentation and microbiological characteristics in the evaluated periods. New studies should be developed with the aim of minimizing the incidence of microorganisms in the haylage to maximize the desired fermentations and to obtain more stable products and better nutritional quality.

\section{CONFLICT OF INTEREST}

We certify that there is no conflict of interest with any financial organization regarding the material discussed in the manuscript.

\section{ACKNOWLEDGMENTS}

The authors are thankful to the Brazilian National Council for Scientific and Technological Development (CNPq), for the financial support for this research project (Process No. 471834/2013-0).

\section{REFERENCES}

1. McDonald P, Henderson N, Heron S. The biochemistry of silage. 2nd ed., Marlow, UK: Chalcombe Publications; 1991. pp. 6-197.

2. Pinho RMA, Santos EM, Carvalho GGP, et al. Microbial and fermentation profiles, losses and chemical composition of silages of buffel grass harvested at different cutting heights. R Bras Zootec 2013;42:850-6.

3. Coblentz WK, Coffey KP, Chow EA. Storage characteristics, nutritive value, and fermentation characteristics of alfalfa packaged in large-round bales and wrapped in stretch film after extended time delays. J Dairy Sci 2016;99:3497-511.

4. Han KJ, McCormick ME, Derouen SM, Blouin DC. Bale location effects on nutritive value and fermentation characteristics of annual ryegrass bale stored in in-line wrapping silage. AsianAustralas J Anim Sci 2014;27:1276-84.

5. Weissbach F, Honig H. About the prediction and control of course of fermentation in the ensilage of green fodder from extensive cultivation. Landbauforschung Volkenrode 1996;1: 10-17.

6. Amaral RC, Santos MC, Daniel JLP, et al. The influence of covering methods on the nutritive value of corn silage for lactating dairy cows. R Bras Zootec 2014;43:471-8.

7. Soil Survey Staff. Keys to soil taxonomy. 12th ed. Washington, DC, USA: United States Department of Agriculture, Natural Resources Conservation Service; 2014.

8. Silva N, Junqueira VCA, Silveira NFA. Manual of methods for the microbiological analysis of food. São Paulo, Brazil: Varela; 1997.

9. Speck ML. Compendium of methods for the microbiological examination of foods. 2nd ed. Washington, DC, USA: American Public Health Association; 1984.

10.Samson RA, Hoekstra ES, Frisvad JC, Filtenborg O. Introduction to food-borne fungi. 4th ed. Baarn, The Netherlands: Centraalbureau voor Schimmelcultures; 1995.

11. Johnson RR, Balwani TL, Johnson LJ, McClure KE, Dehority BA. Corn plant maturity: II Effect on in vitro cellulose digestibility and soluble carbohydrate content. J Anim Sci 1966;25: 617-23.

12. Bolsen KK, Lin C, Brent BE, et al. Effect of silage additives on the microbial succession and fermentation process of alfalfa and corn silages. J Dairy Sci 1992;75:3066-83.

13. Cherney JH, Cherney DJR. Assessing silage quality. In: Buxton DR, Muck R, Harrison J, editors. Silage science and technology. Madison, WI, USA: American Society of Agronomy; 2003. p. 141-98.

14. Weinberg ZG, Chen Y, Miron D, et al. Preservation of total mixed rations for dairy cows in bales wrapped with polyethy- 
lene stretch film - A commercial scale experiment. Anim Feed Sci Technol 2011;164:125-9.

15. Neres MA, Hermes PR, Ames JP, et al. Use of additives and pre-wilting in tifton 85 bermudagrass silage production. Ciênc Agrotec 2014;38:85-93.

16. Coan RM, Reis RA, Garcia GR, et al. Microbiological and fermentative dynamics of tanzaniagrass and marandugrass silage using pelleted citrus pulp as an additive. R Bras Zootec 2007; 36:1502-11.

17. Santos RJC, Lira MA, Guim A, et al. Elephant grass clones for silage production. Sci Agric 2013;70:6-11.

18. Bernardes TF, Reis RA, Moreira AL. Fermentative and microbiological profile of Marandu-grass ensiled with citrus pulppellets. Sci Agric 2005;62:214-20.

19.Li Y, Nishino N. Changes in the bacterial community and composition of fermentation products during ensiling of wilted Italian ryegrass and wilted guinea grass silages. Anim Sci J 2013;84:607-12.

20. Ridwan R, Rusmana I, Widyastuti Y, et al. Fermentation characteristics and microbial diversity of tropical grass-legumes silages. Asian-Australas J Anim Sci 2015;28:511-8.

21.Rammer C, Ostling C, Lingvall P, Lindgren S. Ensiling of manured crops: effects on fermentation. Grass Forage Sci 1994; 49:343-51.

22. Meer RR, Baker J, Bodyfelt FW, Griffiths MW. Psychrotrophic Bacillus spp. in fluid milk products: A review. J Food Prot 1991;
54:969-79.

23. Ni K, Wang Y, Li D, Cai Y, Pang H. Characterization, identification and application of lactic acid bacteria isolated from forage paddy rice silage. PLoS One 2015;10:e0121967.

24.Zopollatto M, Daniel JLP, Nussio LG. Microbial silage additives in Brazil: review of aspects of ensilage and animal performance. R Bras Zootec 2009;38:170-89.

25. Neres MA, Zambom MA, Fernandes T, et al. Microbiological profile and aerobic stability of Tifton 85 bermudagrass silage with different additives. R Bras Zootec 2013;42:381-7.

26.Schocken-Iturrino RP, Reis RA, Coan RM, et al. Chemical and microbiological changes of Tifton 85 grass silage after silos opening. R Bras Zootec 2005;34:464-71.

27. Franco BG, Landgraf M. Microbiologia dos alimentos. São Paulo, Brazil: Atheneu; 2005.

28.Spadaro D, Bustos-Lopez MP, Gullino ML, et al. Evolution of fungal populations in corn silage conserved under polyethylene or biodegradable films. J Appl Microbiol 2015;119:510-20.

29. Dunière L, Sindou J, Chaucheyras-Durand F, Chevallier I, Thévenot-Sergentet D. Silage processing and strategies to prevent persistence of undesirable microorganisms. Anim Feed Sci Technol 2013;182:1-15.

30. Roth G, Undersander D, Allen M, et al. Corn silage production, management and feeding. 21st ed. Madison, WI, USA: American Society of Agronomy; 1995. 